AGRICA: Journal of Sustainable Drayland Agriculture, 14 (2): 113-127 (2021)

ISSN-Online: 2715-4955; ISSN-Cetak: 2715-6613

DOI: 10.37478 /agr.v14i2.1478

\title{
ANALISIS KELAYAKAN USAHA DAN STRATEGI PENGEMBANGAN AGROINDUSTRI KERIPIK UBI KAYU NUABOSI MEREK "QURENA" PADA KELOMPOK PKK DESA RANDOTONDA KABUPATEN ENDE
}

\author{
Willybrordus Lanamana ${ }^{1, *}$, Laurentius Dominicus Gadi Djou ${ }^{2)}$, Kristono Yohanes Fowo ${ }^{1)}$ \\ Yohanes Pande ${ }^{3)}$ \\ ${ }^{1)}$ Program Studi Agroteknologi, Fakultas Pertanian Universitas Flores \\ 2) Program Studi Akuntansi, Fakultas Ekonomi, Universitas Flores \\ 3) Program Studi Ilmu Hukum, Fakultas hukum, Universitas flores \\ Jln. Sam Ratulanggi XX Paupire, Ende, Nusa Tenggara Timur
}

Email: *) wlanamana@yahoo.com

\begin{abstract}
Feasibility analysis of business development strategy for agroindustry of nuabosi timber chips brand "qurena" In randotonda village pkk group Ende district. This study aims to analyze the feasibility of the Nuabosi cassava chips agroindustry with the "Qurena" brand, and formulate a strategy for its development. The research was conducted at the Home Industry for Processing Nuabosi Cassava with the brand "Qurena", managed by the PKK Mobilization Team in Randotonda Village, Ende District. The number of employees is 30 people, including leaders and employees. This research is a population study. The analysis used $\mathrm{R} / \mathrm{C}$ ratio, $\mathrm{B} / \mathrm{C}$ ratio, $\mathrm{ROI}$ and $\mathrm{SWOT}$. The results of the analysis show that the Nuabosi cassava processing industry into "Qurena" brand chips is profitable and feasible, because the $\mathrm{R} / \mathrm{C}$ ratio is $>1$, the $\mathrm{B} / \mathrm{C}$ ratio value for each production cost is $\mathrm{Rp} .100$ then will get a profit of $\mathrm{Rp} .78$, the "Qurena" brand chips business is feasible. The ROI value obtained is $78 \%$, this value can be interpreted that the amount of profit obtained compared to the investment (ROI) invested is good. Each capital of Rp. 100, obtained a profit of Rp. 78. Based on the SWOT analysis it was found that the appropriate development strategy is a progressive strategy that supports the growth of agro-industry businesses, and is in a rapid growth strategy. The Nuabosi cassava chips business with the "Qurena" brand is in a strong position and has the opportunity to be developed.
\end{abstract}

Keywords: Business Feasibility, Cassava, Development Strategy

\section{PENDAHULUAN}

Ubi kayu termasuk salah satu tanaman pangan yang sudah lama dibudidayakan petani secara tradisional dan dikenal luas masyarakat Indonesia. Sampai saat ini ubi kayu merupakan sumber pangan utama karbohidrat setelah padi dan jagung bagi sebagian besar masyarakat. Komoditas ini memiliki cukup banyak varietas lokal, tersedia sepanjang tahun, tahan terhadap serangan hama dan penyakit. Komoditas ini memiliki nilai strategi karena saat ini telah dikembangkan menjadi bioenergy (Ozoegwu et al., 2017). 
Ubikayu potensial untuk dikembangkan sebagai produk pangan olahan, karena memiliki nilai bisnis (Utami \& Dumasari, 2014), namun ubi kayu juga merupakan komoditas yang mudah rusak dan waktu penyimpanan relatif pendek. Beberapa studi menunjukkan pengawetan dan pengolahan ubi kayu menjadi produk olahan seperti kripik merupakan pilihan untuk meningkatkan nilai ekonomis dari ubi kayu (Hamidah et al., 2015). Keripik ubi kayu saat ini tersedia dalam aneka rasa seperti: rasa keju, manis, asin, pedas, manis pedas, rasa udang dan sebagainya (Haloho, 2014.). Masyarakat pedesaan dapat melakukan pengolahan ubi kayu menjadi berbagai bahan pangan, terutama pada saat produksi melimpah dan harga produk rendah. Secara ekonomis hadirnya industri rumah tangga di desa memiliki beberapa keunggulan diantaranya, mudah dan murahnya mendapatkan bahan baku serta nilai tambah perubahan bentuk dapat diterima masyarakat desa (Rahman, 2015). Hadirnya industri rumah tangga memiliki peran strategis dalam penyerapan tenaga kerja dan peningkatan pendapatan rumah tangga (Elisabeth \& Prasetiaswati, 2018; Imran et al., 2014). Ubi kayu Nuabosi merupakan komoditas unggulan Kabupaten Ende, komoditas ini memiliki beberapa kelebihan, diantaranya produktivitas dan kualitas hasil tinggi, rasanya enak dan gurih tekstur lembut dan kadar hidrogen sianida (HCN) rendah. Umbi rebus yang empuk dan gurih tetap dapat dinikmati setelah umbi dingin (pada varietas lokal lain menjadi lebih keras) (Lanamana \& Supardi, 2021). Ukuran umbi yang tidak terlalu besar dengan panjang rata-rata sekitar $50 \mathrm{~cm}$ dan diameter rata-rata sekitar $5.0 \mathrm{~cm}$ dipandang sebagai keunggulan karena lebih mudah dikemas dan diangkut ke luar daerah (Arsa et al., 2015).

Permintaan ubi kayu Nuabosi cukup tinggi, hasil wawancara dengan Kepala Desa Randotonda, produksi ubi kayu Nuabosi selalu laku terjual setiap tahun ditingkat petani. Dari total produksi, $20 \%$ disimpan untuk memenuhi kebutuhan rumah tangga, $80 \%$ dijual petani, $30 \%$ dijual sendiri oleh petani di pasar kabupaten dan $70 \%$ dibeli pedagang di kebun petani. Harga satu ikat (sekitar 3-4 kg) Rp 25.000 dijual di pasar Kabupaten Ende, jika dibeli di kebun petani, harga Rp 20.000 untuk setiap ikat. Petani umumnya mengusahakan lahan ubi kayu antara 0,5-1,0 hektar, dengan hasil panen rata-rata mencapai 7 ton/ha setiap tahun.

Tahun 2020 kelompok PKK Desa Randotonda, memulai usaha pengolahan ubi kayu Nuabosi menjadi beberapa produk pangan turunan, salah satu diantaranya kripik dengan beberapa varian rasa. Pengolahan memiliki fungsi untuk memberi nilai 
Lanamana: Analisis kelayakan usaha dan strategi pengembangan agroindustri keripik ubi kayu Nuabosi

tambah dan memperpanjang masa simpan ubi kayu (Sipayung \& Ginting, 2020). Kegiatan dimulai dengan penyuluhan dan pelatihan, uji coba produk di pasar (tester produk), promosi dan pemasaran. Setelah mendapatkan izin edar dari Dinas Perizinan Satu Atap dan melalui proses survey di lokasi pengolahan oleh Dinas Kesehatan, tim PKK memulai proses produksi secara mandiri dengan merek produk kripik "Qurena".

Kripik ubi kayu Nuabosi merek "Qurena", potensial untuk dikembangkan, kerena bahan dasar ubi kayu merupakan komoditas unggulan daerah. Nama ubi kayu Nuabosi telah memberi tempat tersendiri dihati masyarakat, sebagai komoditas yang memiliki cita rasa enak dan gurih. Hasil survey penulis pada beberapa mini market di Ende tahun 2021, menunjukkan bahwa permintaan kripik ubi kayu Nuabosi cukup tinggi. Pada setiap toko dan mini market kripik ubikayu cukup banyak dengan berbagai merek, demikian juga kripik ubikayu Nuabosi memiliki beberapa pilihan merek dengan berbagai varian rasa dan berbagai kelebihan. Namun menurut penuturan salah satu konsumen di Kabupaten Ende, terdapat krisis kepercayaan antara pengusaha kripik ubikayu dengan konsumen yang disebabkan banyak pelaku bisnis palsu atau produk yang dijual bukanlah kirpik yang berasal dari ubikayu Nuabosi.
Pemasaran kripik ubikayu Nuabosi merek "Qurena" dilakukan dengan menitipkan pada kios-kios dan mini market yang ada di wilayah Kabupaten Ende dan kabupaten tetangga. Usaha kripik ubikayu Nuabosi diharapkan mampu memberikan nilai tambah dan peningkatan pendapatan bagi masyarakat desa. Nilai tambah merupakan penambahan nilai yang lebih tinggi melalui suatu proses produksi/pengolahan dari suatu produk (Arianti \& Waluyati, 2019). Untuk itu perlu dilakukan studi untuk mengetahui kelayakan usaha dari suatu industri pengolahan (Santosa, 2017).

Suatu usaha bisnis perlu dilakukan kajian untuk mendapatkan informasi yang akurat tentang layak atau tidak layak usaha yang dirintis tersebut. Informasi ini diperlukan oleh manajemen atau pemilik usaha untuk melakukan langkah-langkah strategis. Studi kelayakan bisnis dilakukan dengan memberi penilaian dari berbagai aspek secara komprehensif. Studi kelayakan bisnis dapat juga dikatakan sebagai suatu peramalan yang mumpuni yang dapat dipertanggungjawabkan secara ilmiah (Sajari et al., 2017).

Produk agroindustri harus memiliki kualitas yang baik, harga jual yang kompetitif dan pertumbuhan usaha yang terus meningkat. Untuk itu perlu dirancang suatu strategi pengembangan yang efektif. Kemampuan 
mengidentifikasi faktor-faktor internal dan eksternal dalam suatu matriks SWOT secara objektif membantu sebuah industri rumah tangga dalam mendisain strategi pengembangan baik jangka pendek, menengah dan panjang. Merujuk pada latar belakang di

\section{METODE PENELITIAN}

\section{Lokasi dan Waktu Penelitian}

Penelitian dilakukan diindustri rumah tangga pengolahan ubikayu Nuabosi merek "Qurena", milik Tim Penggerak PKK Desa Randotonda, Kecamatan Ende. Jumlah pekerja 30 orang termasuk pimpinan dan karyawan. Pemilihan lokasi penelitian dengan pertimbangan: a) Industri rumah tangga ini merupakan salah satu industri yang memproduksi kripik dari ubikayu varietas lokal Nuabosi, yang merupakan komoditas unggulan kabupaten Ende. b) Merupakan industri rumah tangga rintisan dari tahun 2020, semenjak mendapatkan dana hibah pengabdian kepada masyarakat skema Program Pengembangan Desa Mitra (PPDN) dari Kemenristek-Brin untuk 3 tahun pendanaan. c) Industri rumah tangga ini merupakan satu-satunya industri milik masyarakat desa yang dikelola oleh tim penggerak PKK. Penelitian dilaksanakan pada bulan April sampai Juni 2021.

\section{Populasi.}

atas, maka penelitian ini bertujuan untuk menganalisis kelayakan usaha agroindustrikripik ubikayu Nuabosi merek "Qurena", dan merumuskan strategi pengembangannya.

Populasi dalam penelitian ini adalah pimpinan dan karyawan, industri rumah tangga kripik dengan merek "Qurena".Jumlah karyawan 30 orang, karena jumlahpopulasi terbatas hanya 30 orang, maka 30 orang diambil untuk dijadikan responden. Penelitian ini merupakan penelitian populasi.

\section{Analisa Data}

a. Pendapatan: Rumus $\mathrm{TR}=P \cdot Q$ Keterangan:

$$
\begin{aligned}
& \text { TR = Total pendapatan (Rupiah) } \\
& \mathrm{Q}=\text { Total produk yang terjual }(\mathrm{Kg}) \\
& \mathrm{P}=\text { Harga produk (Rupiah) }
\end{aligned}
$$

b. Keuntungan: Rumus; $\Pi=\mathrm{TR}$ - TC

Keterangan:

$\Pi=$ Keuntungan

$\mathrm{TR}=$ Total revenue/penerimaan

$\mathrm{TC}=$ Biaya total.

c. Analisis Kelayakan Bisnis (R/C Ratio)

Analisis layak tidaknya usaha industri rumah tangga pengolahan kripik ubikayu Nuabosi, menggunakan rumus $\mathrm{R} / \mathrm{C}$ ratio; membandingkan tingkat pendapatan yang diperoleh dengan modalyang dikeluarkan. 
Lanamana: Analisis kelayakan usaha dan strategi pengembangan agroindustri keripik ubi kayu Nuabosi

Standar yang digunakan $\mathrm{R} / \mathrm{C}$ ratio > 1: Rumus $\mathrm{R} / \mathrm{C}$ ratio

1. $\mathrm{R} / \mathrm{C}$ ratio $=\frac{\text { Total Pendapatan }}{\text { Total Biaya }}$ Dengan ketentuan:

a) R/C > 1 = Layak / Untung

b) $\mathrm{R} / \mathrm{C}=1=\mathrm{BEP}$

c) $\mathrm{R} / \mathrm{C}<1$ = Tidak Layak / Rugi

2. B/C Ratio (Benefit cost ratio)

Perbandingan antara pendapatan $($ Benefit $=\mathrm{B})$ dengan total biaya produksi $($ Cost $=\mathrm{C})$. Rumus:B/C ratio $=$ Jumlah Keuntungan(B)/ Total Biaya Produksi (TC). Dengan ketentuan; Jika $\mathrm{B} / \mathrm{C}$ ratio $>0$, bisnis layak dilaksanakan. Jika $\mathrm{B} / \mathrm{C}$ ratio < 0 , bisnis tidak layak ataumerugi

\section{ROI}

Rasio keuntungan bersih terhadap biaya. Rumus ROI sebagai berikut:

ROI $=\frac{\text { Keuntungan }}{\text { Total Biaya }} \times 100 \%$

d. Analisis SWOT

Strategi pengembangan usaha kripik ubikayu Nuabosi merek "Qurena" menggunakan analisis SWOT. Pada analisis ini dilakukan penentuan faktor-faktor internal dan eksternal, diberi bobot, rating dan skor, digambarkan matriks SWOT, kemudian dirumuskan strategi pengembangannya. Dengan analisis SWOT, kekuatan (Strenghts) dan peluang (Opportunities) dapat dimaksimalkan, namun secara bersamaan dapat meminimalkan kelemahan (Weaknesses) dan ancaman (Threats) (Hermawan, 2014; Evalia, 2015; Arianti \& Waluyati, 2019).

\section{HASIL DAN PEMBAHASAN}

\section{Biaya Produksi}

a. Biaya Tetap

Komponen biaya yang diperhitungkan sebagaibiaya tetap pada industri rumah tangga kripik "Qurena" adalah biaya penyusutan peralatan. Peralatan yang digunakan meliputi; pengiris singkong, wajan, kompor, serokan, sutel, penyaring minyak, keranjang industri, baskom, serbet, ember., gayung, sikat, dan pisau. Biaya penyusutan peralatan diperoleh dari jumlah unit dikali dengan harga beli dibagikan dengan umur ekonomis. Nilai penyusutan per/bulan dibagi 12 bulan (Sajari et al., 2017). Rata-rata biaya penyusutan atau biaya tetap industri rumah tangga pengolahan ubikayu Nuabosi menjadi kripik pada Tabel 1. 
Tabel 1. Rata-Rata Biaya Tetap Pada Industri Pengolahan Ubikayu Nuabosi Menjadi Kripik

\begin{tabular}{llccrrr}
\hline No & Uraian Biaya & $\begin{array}{c}\text { Jumlah } \\
\text { (Unit) }\end{array}$ & $\begin{array}{c}\text { Umur } \\
\text { Ekonomis } \\
\text { (Thn) }\end{array}$ & $\begin{array}{c}\text { Harga } \\
\text { RP/unit }\end{array}$ & $\begin{array}{c}\text { Jumlah } \\
\text { Rp }\end{array}$ & $\begin{array}{c}\text { Nilai } \\
\text { Penyusutan } \\
\text { (Rp/bln) }\end{array}$ \\
\hline 1. & Bangunan & 1 & 6 & 15.000 .000 & 15.000 .000 & 208.333 \\
2 & Pengiris singkong & 2 & 8 & 4.000 .000 & 8.000 .000 & 83.000 \\
3 & Wajan & 2 & 4 & 307.500 & 615.000 & $12.812,5$ \\
4 & Kompor & 5 & 3 & 680.000 & 3.400 .000 & 94.444 \\
5 & Serokan & 4 & 2 & 37.500 & 150.000 & 6250 \\
6 & Sutel & 4 & 2 & 50.000 & 200.000 & 8.333 \\
7 & Penyaring minyak & 1 & 2 & 100.000 & 100.000 & 4166 \\
8 & Keranjang industri & 2 & 7 & 125.000 & 250.000 & 2976 \\
9 & Baskom & 4 & 3 & 250.000 & 1.000 .000 & 27.777 \\
10 & Ember & 3 & 2 & 75.000 & 225.000 & 9375 \\
11 & Gayung & 3 & 2 & 7500 & 22.500 & 937.5 \\
12 & Sikat & 3 & 2 & 5000 & 15.000 & 625 \\
13 & Pisau & 4 & 2 & 15.000 & 60.000 & 2500 \\
\hline \multicolumn{2}{r}{ Total } & & & 20.652 .500 & 29.037 .500 & 460.592 \\
\hline
\end{tabular}

Biaya tetap yang harus dikeluarkan oleh industri rumah tangga kripik ubikayu Nuabosi berdasarkan data pada Tabel 1, berupa penyusutan sebesar 460.592 Rata-rata biaya penyusutan per peralatan terbesar pada bangunan dan terkecil pada penyusutan sikat. Bangunan yang digunakan adalah bangunan lama milik Desa Randotonda, dari perhitungan fisik bangunan nilai ekonomis tinggal 6 tahun.

b. Biaya Variabel

Biaya variabel pembuatan kripik ubikayu Nuabosi merek "QURENA" meliputi; biaya bahan baku (bahan baku utama dan penunjang), biaya bahan bakar, kemasan, biaya tenaga kerja dan transportasi.

1) Biaya Bahan Baku dan Bahan Penunjang

Bahan baku utamayang digunakan adalah ubikayu varietas lokal Nuabosi dipanen petani di Desa Randotonda. Jumlah bahan baku yang dibutuhkan untuk satu kali produksi sebanyak $450 \mathrm{~kg}$, dengan harga Rp. 8000/ kg. Harga/kg ubikayu Nuabosi relatif lebih mahal dibandingkan dengan ubikayu lokal lainnya. Bahan penunjang yang digunakan meliputi; bawang putih, cabai kriting hijau dan merah, garam, minyak goreng, jahe, dan gula, bahan bakar berupa minyak tanah. Jumlah biaya bahan baku dan 
Lanamana: Analisis kelayakan usaha dan strategi pengembangan agroindustri keripik ubi kayu Nuabosi

penunjang untuk satu periode produsi pada Tabel 2.

Tabel 2. Biaya Bahan Baku dan Bahan Penunjang per Periode Produksi

\begin{tabular}{llrrr}
\hline No & \multicolumn{1}{c}{ Uraian Biaya } & Jumlah & $\begin{array}{r}\text { Harga Satuan } \\
\text { (Rp) }\end{array}$ & \multicolumn{1}{c}{$\begin{array}{c}\text { Jumlah } \\
\text { (RP) }\end{array}$} \\
\hline 1 & Ubikayu & $450 \mathrm{~kg}$ & 8000 & 3.600 .000 \\
2 & Bawang putih & $2 \mathrm{~kg}$ & 28.000 & 56.000 \\
3 & Cabai kriting merah & $1 \mathrm{~kg}$ & 75.000 & 75.000 \\
4 & Cabai kriting hijau & $1 \mathrm{~kg}$ & 75.000 & 75.000 \\
5 & Garam & $2 \mathrm{bks}$ & 5.000 & 10.000 \\
6 & Minyak goreng & $5 \mathrm{ltr}$ & 85.000 & 85.000 \\
7 & Jahe & $1 \mathrm{~kg}$ & 35.000 & 35.000 \\
8 & Mentega & $2 \mathrm{~kg}$ & 14.000 & 28.000 \\
9 & Gula pasir & $2 \mathrm{~kg}$ & 14.000 & 28.000 \\
\hline \multicolumn{2}{l}{ Total biaya } & & 3.992 .000 \\
\hline
\end{tabular}

Data pada Tabel 2 menunjukkan bahwa total biaya bahan baku dan bahan penunjang yang dibutuhkan untuk satu kali proses produksi kripik "Qurena" sebesar Rp. 3.992.000. Komponen biaya yang paling besar pada biaya pembelian ubikayu Nuabosi sebesar $90 \%$ dari total biaya bahan baku dan bahan penunjang. Hal ini disebabkan harga jual/ kg ubikayu Nuabosi relatif mahal Rp. 8000/ kg. Biaya paling rendah, pembelian garam.

2). Biaya Bahan Bakar

Bahan bakar yang digunakan dalam proses produksi yaitu minyak tanah. Untuk satu kali proses produksi dibutuhkan 15 liter dengan harga 1 liter Rp. 6.000. Biaya yang dibutuhkan untuk 1 kali proses produksi sebesar Rp. 90.000.

3). Biaya Tenaga Kerja
Jumlah tenaga kerja yang terlibat dalam proses produksi sebanyak 15 orang, dengan pembagian pekerjaan, 2 orang tenaga kerja pengupasan, 2 orang pencucian, 2 orang pengiris, 2 orang pembuatan bumbu (rasa balado hijau, belado merah, asin manis, dan original), 2 orang penggorengan, 2 orang pemberi bumbu pada kripik, 2 orang pengemasan dan pengepakan, 1 orang promosi sertapemasaran. Perhitungan biaya tenaga kerja dalam bentuk fisik yaitu dengan hari orang kerja (HOK). Satu HOK tujuh jam kerja atau sama dengan satu hari kerja pria, Sistem pengupahan menggunakan sistem mingguan, jumlah hari kerja 6 hari. Setiap minggu setiap pekerja mendapat upah yang sama sebesar Rp. 300.000. Dengan jumlah tenaga kerja sebanyak 15 orang, biaya tenaga kerja untuk per proses produksi selama 1 
AGRICA, VOL. 14, NO. 2 (2021)

minggu sebesar Rp. 4.500.000 Upah tersebut diberikan setelah pekerjaan selesai.

4). Biaya Transportasi

Biaya transportasi merupakan biaya yang dikeluakan untuk pemasarankripik ubikayu Nuabosi ke kota Ende. Besar biaya yang dikeluarkan Rp. 400.000/proses produksi. Kripik diantar pada konsumen yang sudah memesan dan didistribusikan pada beberapa mini market.

\section{5). Biaya Kemasan}

Kemasan yang digunakan berbahan plastik, dibeli di minimarket, kemasan plastik tersebut kemudian diberi stiker, berupa labeling yang sudah mencantumkan merek, komposisi, harga, masa kedaluarsa, kode produksi dan izin edar. Harga 1 plastik ukuran 200 grm Rp 1000, stiker 1500/ buah. Pesanan untuk 1000 kemasan terperinci pada Tabel 3.

Tabel 3. Biaya Kemasan

\begin{tabular}{llccr}
\hline No & Uraian & Jumlah & Harga/buah (Rp) & Total (Rp) \\
\hline 1 & Kemasan Plastik & 1000 & 1000 & 1.000 .000 \\
2 & Stiker & 1000 & 750 & 750.000 \\
\hline & Total Biaya Kemasan & & & 1.750 .000 \\
\hline
\end{tabular}

\section{Total Biaya Variabel}

Besarnya biaya variabel yang dikeluarkan untuk beberapa komponen biaya tersebut di atas yaitu, biaya bahan baku dan penunjang Rp. 3.992.000, biaya bahan bakar Rp. 90.000 biaya tenaga kerja Rp. 4.500.000, biaya transportasi Rp. 400.000, dan biaya kemasan Rp. 1.750.000. Total biaya variabel Rp. 10.732.000

2. Total Biaya Produksi

Total biaya yang dikeluarkan untuk memproduksi kripik Ubikayu Nuabosi sebesar Rp. 9.442.592. Secara terperinci pada Tabel 4.

Tabel 4. Total Biaya Produksi Kripik Ubikayu Nuabosi per Minggu

\begin{tabular}{ccc}
\hline No & Biaya & Jumlah Biaya \\
\hline 1 & Total Biaya Tetap & 460.592 \\
2 & Total Biaya Variabel & 10.732 .000 \\
\hline & Total Biaya & 11.192 .592 \\
\hline
\end{tabular}

\section{Analisis Penerimaan}

Analisis penerimaan dapat memberi gambaran berhasil tidaknya usaha kripik ubikayu Nuabosi merek “Qurena”. Hasil dari analisis penerimaan akan dilanjutkan dengan analisis ekonomi lainnya. Secara terperinci penerimaan dari usaha kripik ubikayu Nuabosi pada Tabel 4. 
Lanamana: Analisis kelayakan usaha dan strategi pengembangan agroindustri keripik ubi kayu Nuabosi

Tabel 4. Jumlah Penerimaan Industri Keripik "Qurena” per Periode Produksi

\begin{tabular}{llccc}
\hline No & Uraian & $\begin{array}{c}\text { Jumlah Produksi } \\
\text { (kemasan ukuran 200 gr) }\end{array}$ & $\begin{array}{c}\text { Harga } \\
(\mathrm{Rp})\end{array}$ & $\begin{array}{c}\text { Nilai Produk } \\
\text { Rp/minggu }\end{array}$ \\
\hline 1 & Kripik Ubikayu Nuabosi & 1000 kemasan & 20.000 & 20.000 .000 \\
\hline
\end{tabular}

4. Analisis Keuntungan

Analisis keuntungan memberi gambaran besarnya pendapatan yang diperoleh setelah dikurangi biaya-biaya produksi.Analisis ini membantu manajemen untuk melakukan pertimbangan secara ekonomis usahanya. Berdasarkan data pada
Tabel 5. Keuntungan yang diperoleh industrikripik ubikayu Nuabosi merek “Qurena” sebesar 8.807.408/ minggu. Rincian perhitungan keuntungan yang diperoleh industri kripik Ubikayu Nuabosi pada Tabel 5 .

Tabel 5 Keuntungan Industri Kripik Ubikayu Nuabosi “Qurena” Per Minggu

\begin{tabular}{clcc}
\hline No & & Uraian & Jumlah $(\mathrm{Rp} /$ minggu $)$ \\
\hline \multirow{2}{*}{1} & Total Penerimaan & & 20.000 .000 \\
& Total Biaya & & 11.192 .592 \\
\hline & & Keuntungan & 8.807 .408 \\
\hline
\end{tabular}

5. Analisis Kelayakan Usaha

Layak atau tidak layaknya industri rumah tangga kripik ubikayu Nuabosi merek "Qurena", didasarkan pada rasio nilai Revenue dengan Cost ( $\mathrm{R} / \mathrm{C}$ ratio), Benefit dengan Cost $(\mathrm{B} / \mathrm{C})$ ratio, dan Return on Investment (ROI)(Wulandari et al., 2019).

\section{Revenue/Cos $(R / C)$}

Revenue costmerupakan perbandingan antara penerimaan dengan total biaya. Perhitungan analisis revenue /costsebagai berikut.

$$
\begin{aligned}
& \mathrm{R} / \mathrm{C}=20.000 .000 / 11.192 .592 \\
& \mathrm{R} / \mathrm{C}=1,78
\end{aligned}
$$

Berdasarkan hasil perhitungan tersebut, maka dapat dijelaskan bahwa usaha industri pengolahan ubikayu Nuabosi menjadi kripik, menguntungkan, dan layak diusahakan, karena nilai $\mathrm{R} / \mathrm{C}$ ratio > 1 . Setiap pengeluaran Rp. 100 memberi penerimaan sebesar Rp. 178.

\section{Benefit/Cost (B/C) Ratio}

Perhtiungan (B/C) Ratio sebagai berikut:

$\mathrm{B} / \mathrm{C}=8.807 .408 / 11.192 .592$

$\mathrm{B} / \mathrm{C}=0,78$

Nilai B/C ratio dapat diartikan bahwa, setiap biaya produksi yang dikeluarkan sebesar Rp. 100 maka akan memperoleh keuntungan 
sebesar Rp. 78. Usaha kripik ubikayu Nuabosi layak untuk diusahakan.

\section{Return On Investment (ROI)}

Perhitungan ROI sebagai berikut:

$\mathrm{ROI}=\underline{8.807 .408} \times 100 \%$

$$
\begin{aligned}
& 11.192 .592 \\
& \text { ROI }=78 \%
\end{aligned}
$$

\section{Analisis Matriks IFAS dan EFAS}

\section{a. Matriks IFAS}

Data pada Tabel 6 menunjukkan bahwa faktor-faktor internal yang mempunyai skorkekuatan tertinggi adalah kualitas produk keripik ubikayu Nuabosi dan bahan baku ubikayu Nuabosi. Nilai bobot sebesar 0,121 dengan rating 4 , score 0,484 . Kedua faktor kunci inimerupakan kekuatan utama, didukung dengan aktivitas promosi, harga produk yang ekonomis dan memiliki jaringan distribusi cukup baik. Matriks IFAS juga menunjukkan berbagai kelemahan dari
Nilai ROI yang diperoleh sebesar $78 \%$, nilai ini dapat diartikan bahwa, bahwa besarnyakeuntungan yang diperoleh dibandingkaninvestasi (ROI) yang ditanamkan adalah baik.Setiapmodal sebesar Rp. 100, diperoleh keuntungan sebesar Rp. 78.

usahakeripik ubikayu Nuabosi. Faktor internal yang menjadi kelemahan terbesaradalah keterbatasan modal, nilai bobot 0,111 dengan rating 2 sehingga skornya adalah 0,222.Nilai skor yang diperoleh pada hasil analisis matriks IFAS sebesar 2,433, nilai ini menunjukkan bahwa usaha kripik ubikayu Nuabosi berada pada level rata-rata didalam kekuatan internal seluruhnya, sehingga dituntut dalam memanfaatkan kekuatan dan meminimalisir kelemahan lebih optimal.

Tabel 6 Matriks IFAS Usaha Kripik Ubikayu Nuabosi Merek "Qurena”

\begin{tabular}{clccc}
\hline No & \multicolumn{1}{c}{ Faktor-Faktor Internal } & Bobot & Rating & Skor \\
\cline { 2 - 3 } & \multicolumn{1}{c}{ Kekuatan } & 0,121 & 4 & 0,484 \\
\hline 1 & Bahan baku ubikayu selalu tersedia & 0,121 & 4 & 0,484 \\
3 & Kualitas produk yang baik & 0,111 & 3 & 0,333 \\
4 & Memiliki izin edar dan sertifikasi halal & 0,110 & 3 & 0,330 \\
5 & Memiliki jaringan distribusi yang baik & 0,111 & 3 & 0,333 \\
6 & Sering melakukan promosi & 0,101 & 3 & 0,303 \\
& Harga produk ekonomis & & & 1,783 \\
& Total Kekuatan & & & \\
1 & Kelemahan & & & 0,022 \\
2 & Keknologi & 0,011 & 2 & 0,222 \\
3 & Teterbatasan modal & 0,111 & 2 & 0,204 \\
4 & Pengat produksi tidak memadai & 0,102 & 2 & 0,202 \\
& kurang memadai & 0,101 & 2 &
\end{tabular}


Lanamana: Analisis kelayakan usaha dan strategi pengembangan agroindustri keripik ubi kayu Nuabosi

\begin{tabular}{lll} 
Total Kelemahan & 1 & 0,650 \\
Total & & 2,433 \\
\hline S - W & 1,133 \\
\hline
\end{tabular}

\section{b. Matriks EFAS}

Data pada Tabel 7 menunjukkan bahwa faktor-faktor eksternal yang memberikan peluang terbesar adalah permintaan relatif tinggi, dengan nilai bobot 0,330 , rating 4 serta total skor 1,320..Permintaan yang cukup tinggi dipengaruhi oleh bahan baku utama kripik ubikayu tersebut berasal dari varietas ubikayu lokal Nuaboasi yang memiliki tesktur yang lembut serta rasa yang gurih. Komoditas tersebut telah dijadikan komoditas unggulan Kabupaten Ende.

Tabel 7 Matriks EFAS Usaha Kripik Ubikayu Nuabosi Merek "Qurena”

\begin{tabular}{clccc}
\hline No & \multicolumn{1}{c}{ Faktor-Faktor Internal } & Bobot & Rating & Skor \\
\cline { 2 - 3 } & Peluang & 0,330 & 4 & 1,320 \\
\hline 1 & Permintaan relatif tinggi & 0,210 & 3 & 0,630 \\
& $\begin{array}{l}\text { Pendampingan dari lembaga pendidikan } \\
\text { tinggi }\end{array}$ & & & \\
3 & $\begin{array}{l}\text { Dukungan dari masyarakat dan Pemda } \\
\text { Total Peluang }\end{array}$ & & 3 & 0,420 \\
& Ancaman & & & 2,370 \\
1 & Pesaing & 0,200 & 3 & 0,600 \\
2 & Teknologi baru & 0,120 & 3 & 0,360 \\
& Total Ancaman & 1 & & 0,960 \\
& Total & & & 3,330 \\
O - T & & & & 1,410 \\
\hline
\end{tabular}

Faktor-faktor eksternal dengan ancaman terbesar adalah pesaing, nilai bobot 0,200, rating 3 dan skor sebesar 0,600. Data ini menunjukkan tingginya kompetisi usaha keripik ubikayu Nuabosi. Di Kabupaten Ende industri rumah tangga dengan memakai nama kripik ubikayu Nuabosi ada 2 unit usaha, dimiliki oleh pengusaha kota Ende, sedangkan usaha kripik ubikayu Nuabosi dengan merek “Qurena”, dimiliki kelompok PKK yang merupakan petani ubikayu Nuabosi. Kelebihan kripik ini adalah ubikayu asli Nuabosi, dibudidaya secara organik, proses produksi dilakukan setelah ubi baru dipanen, serta bumbu diproduksi sendiri untuk menghindari bahan pengawet. Nilai skor hasil analisis matriks EFAS pada usaha kecil kripik ubikayu Nuabosi sebesar 3,330. Nilai ini mengandung arti bahwa, usaha tersebut berada pada level menengah; strategi yang ditempuh bagaimana memanfaatkan peluang dan menghindari ancaman.

\section{Pemetaan Usaha Kripik Ubikayu Nuabosi Merek "Qurena"}


Menentukan posisi usaha kirpik ubikayu Nuabosi merek "Qurena” dengan cara memadukan kekuatan, kelemahan, ancaman dan peluang, sehingga dapat ditentukan titik koordinat dan dipetakan pada matriks posisi (Palit et al., 2017).

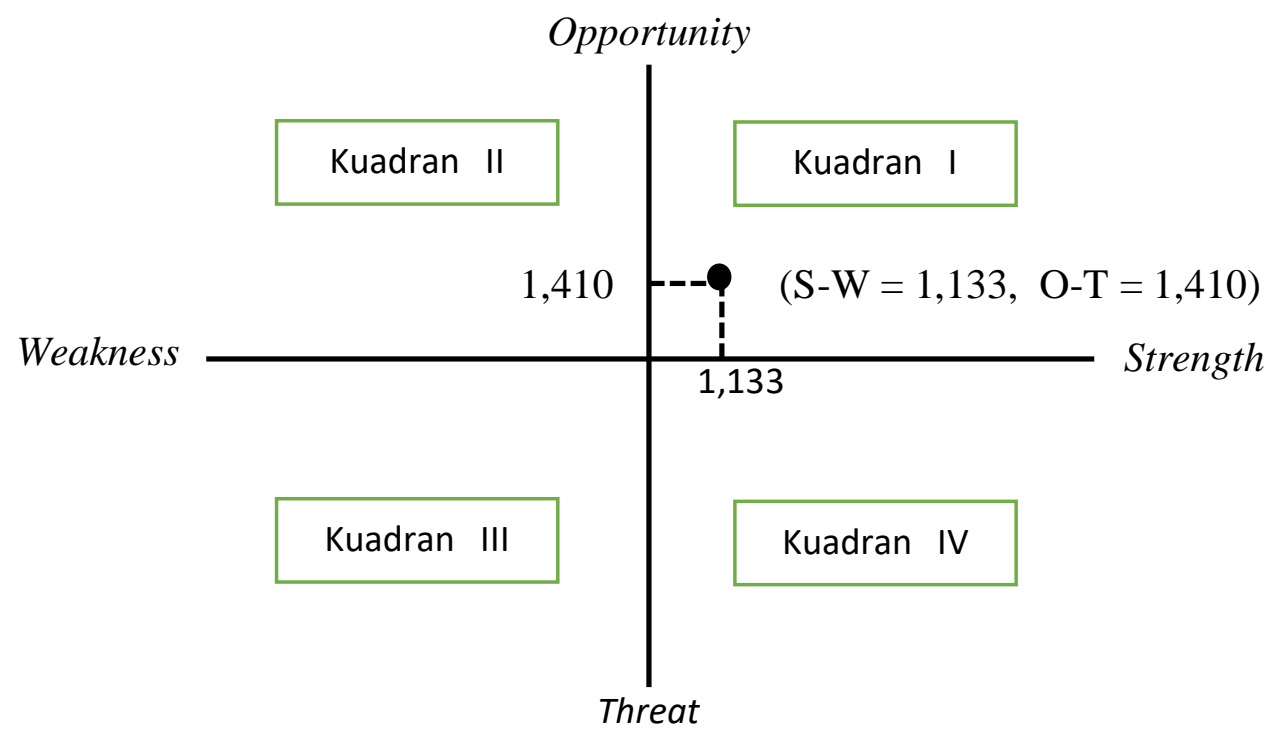

Gambar 1. Matriks Posisi Pengembangan Usaha Kripik Ubikayu Nuabosi Merek "Qurena"

Gambar 1 memberi penjelasan bahwa posisi relatif usaha kripik ubikayu Nuabosi merek "Qurena" berada pada titik koordinat (1.133, 1.410) pada kuadran I yang menunjukan bahwa usaha kripik ubikayu Nuabosi merek "Qurena" dapat memanfaatkan peluang yang ada dengan menggunakan kekuatan yang dimiliki. Strategi pengembangan yang sesuai adalah strategi progresif yang mendukung pada pertumbuhan usaha agroindustri, dan berada pada rapid growth strategy (strategi pertumbuhan cepat).

D. Staretgi Pengembangan
Alternatif strategi dalam pengembangan industri rumah tangga kripik ubikayu Nuabosi merek “Qurena”sebagai berikut:

1. Strategi SO

a. Membuka tempat-tempat penitipan kripik ubikayu Nuabosi pada semua toko dan mini market di Kabupaten dalam wilayah Propinsi NTT

b. Melakukan pemasaran online

c. Melakukan kerjasama dengan perguruan tinggi untuk melakukan riset pasar

d. Meningkatkan promosi di media cetak, media online dan menyelenggarakan beberapa even 
Lanamana: Analisis kelayakan usaha dan strategi pengembangan agroindustri keripik ubi kayu Nuabosi

bersama pemda, dengan tema pemanfaatan pangan lokal untuk meningkatkan ekonomi rumah tangga

\section{Strategi ST}

a. Menjaga ciri khas dari kripik ubikayu Nuabosi

b. Meningkatkan promosi di media cetak, media online dan menyelenggarakan beberapa even bersama pemda, dengan tema pemanfaatan pangan lokal untuk meningkatkan ekonomi rumah tangga

c. Peningkatan sumberdaya manusia pengelola usaha kripik melalui berbagai pelatihan; kewirausahaan, penentuan harga jual, pembuatan proposal untuk mendapatkan pendanaan dari perbankan

\section{Strategi WO}

a. Peningkatan sumberdaya manusia pengelola kripik ubikayu Nuabosi melalui pelatihan-pelatihan; kewirausahaan, penyusunan proposal untuk pemiinjaman dan di bank, penentuah harga pokok produksi dan harga jual, pelatihan penggunaan alat pengolahan yang lebih baik misalnya, spiner (mesin peniris minyak dan sebagainya) b. Mengajukan permohonan ke Pemda untuk dibantu sebuah rumah industri yang layak.

\section{Strategi WT}

a. Meningkatkan promosi di media cetak, media online dan menyelenggarakan beberapa even bersama pemda, dengan tema pemanfaatan pangan lokal untuk meningkatkan ekonomi rumah tangga

b. Melakukan pelatihan-pelatihan peningkatan sumberdaya pengelola usaha kripik ubikayu Nuabosi

Beberapa penjelasan di atas, menunjukkan bahwa usaha kripik ubikayu Nuabosi merek “Qurena”berada pada posisi yang kuat dan berpeluang untuk di kembangkan. Rekomendasi strategi, yaitu progresif, artinya usaha kripik ubikayu Nuabosi memungkinkan untuk melakukan ekspansi, meningkatkan pertumbuhan dan meraih keuntungan secara maksimal. Rekomendasi strategi yang diberikan dari beberapa alternatif strategi di atas adalah Strategi S-O.membuka tempat-tempat penitipan kripik ubikayu Nuabosi pada semua toko dan mini market di Kabupaten dalam wilayah Propinsi NTT, melakukan pemasaran online, melakukan kerjasama dengan perguruan tinggi untuk melakukan riset pasar, meningkatkan promosi di media 
cetak, media online dan menyelenggarakan beberapa even bersama pemda, dengan tema pemanfaatan pangan lokal untuk meningkatkan ekonomi rumah tangga.

\section{SIMPULAN}

Usaha industri rumah tangga kripik ubikayu Nuabosi merek "Qurena"menguntungkan dan layak untukdiusahakan karena memiliki R/C sebesar 1,78 sedangkan $\mathrm{B} / \mathrm{C} \quad 0,78$ danROI diperoleh nilai sebesar 78\%. Strategi pengembangan usaha kripik ubikayu Nuabosi adalah strategi pertumbuhan cepat, beberapa startegi yang dapat diterapkan meliputi: membuka tempat-tempat penitipan kripik ubikayu Nuabosi pada semua toko dan mini market di Kabupaten dalam wilayah Propinsi NTT, melakukan pemasaran online, melakukan kerjasama dengan perguruan tinggi untuk melakukan riset pasar, dan

\section{DAFTAR PUSTAKA}

Arianti, Y. S., \& Waluyati, L. R. (2019). Analisis Nilai Tambah dan Strategi Pengembangan Agroindustri Gula Merah di Kabupaten Madiun. Jurnal Ekonomi Pertanian Dan Agribisnis, 3(2), 256-266. https://doi.org/10.21776/ub.jepa.2019.0 03.02 .4

Arsa, I. G. B. ., Ndiwa, A. S. ., \& Seran, M. Y. (2015). Usulan Pelepasan Geragaan Ubikayu Varietas Nuabosi sebagai Calon Varietas Unggul (F. P. U. N. C. meningkatkan promosi di media cetak, media online dan menyelenggarakan beberapa even bersama pemda, dengan tema pemanfaatan pangan lokal untuk meningkatkan ekonomi rumah tangga.

\section{UCAPAN TERIMAKASIH}

Penelitian ini merupakan tindaklanjut dari kegiatan pengabdian kepada masyarakatskema PPDM tahun 2021 dengan judul Pengembangan Desa Sentral Pangan Olahan Berbasis Ubikayu Nuabosi. Produk yang dihasilkan berupa kripik, penelitian ini bermaksud menganalisis kelayakan bisnis usaha industri rumah tangga kripik merek "Qurena" untuk mendapat informasi layak atau tidak layak produk tersebut diusahakan lebih lanjut. Untuk itu penulis menyampaikan ucapan terimakasih kepada Kemdikbud-Ristek, yang telah membantu pendanaan penelitian ini.

\& D. P. dan P. K. Ende (ed.)). Fakultas Pertanian Universitas Nusa Cendana \& Dinas Pertanian dan Peternakan Kabupaten Ende.

Evalia, N. A. (2015). Strategi Pengembangan Agroindustri Gula Semut Aren. Jurnal Manajemen Dan Agribisnis, 12, 1-11. https://jurnal.ipb.ac.id/index.php/jmagr/ article/view/10066

Haloho, J. D. (n.d.). Diversivikasi Pangan di Kalimantan Barat. Baharsyah 1994, 775-786.

Hamidah, M., Yusra, A. H., \& Sudrajat, J. 
Lanamana: Analisis kelayakan usaha dan strategi pengembangan agroindustri keripik ubi kayu Nuabosi

(2015). Analisis Nilai Tambah Agroindustri Kripik Ubi di Kota Pontianak. Jurnal Social Economic of Agriculture,4, 60-73. https://media.neliti.com/media/publicati ons/23067-ID-analisis-nilai-tambahagroindustri-kripik-ubi-di-kotapontianak.pdf

Hermawan, H. (2014). Pengembangan Destinasi Wisata Pada Tingkat Tapak Lahan Dengan Pendekatan Analisis Swot. 64-74.

Imran, S., Murtisari, A., \& Murni, N. K. (2014). Analisis Nilai Tambah Keripik Ubi Kayu di UKM Barokah Kabupaten Bone Bolango Jurusan Agribisnis Fakultas Pertanian Universitas Negeri Gorontalo. 1(4), 207-212.

Elisabeth, Dian Ady Anggreni\&. Prasetiaswati, Nila (2018). Kelayakan Finansial dan Nilai Tambah Pengolahan Ubi Kayu di Barito Koala, Kalimantan Selatan Processing.

Lanamana, W., \& Supardi, P. N. (2020). A Comparison of Economic Efficiency of Monoculture and Multiple Cropping Patterns: The Case of Cassava Farming in Ende, Indonesia. Caraka Tani: Journal of Sustainable Agriculture, $36(1)$, 69. https://doi.org/10.20961/carakatani.v36i 1.41784

Ozoegwu, C. G., Eze, C., Onwosi, C. O., Mgbemene, C. A., \& Ozor, P. A. (2017). Biomass and bioenergy potential of cassava waste in Nigeria: Estimations based partly on rural-level garri processing case studies. Renewable and Sustainable Energy Reviews, 625-638. https://doi.org/10.1016/j.rser.2017.01.0
31

Palit, I. G., Talumingan, C., \& Rumagit, G. A. . (2017). Strategi Pengembangan Kawasan Agrowisata Rurukan. Agri Sosio Ekonomi Unsrat, 13, 21-34. https://scholar.google.com/scholar?hl=i d\&as_sdt $=0 \% 2 \mathrm{C} 5 \& \mathrm{q}$

Rahman, S. (2015). Analisis Nilai Tambah Agroindustri Chips Jagung.Jurnal Aplikasi Teknologi Pangan4(3), 108111.

Sajari, I., Elfiana, \& Martina. (2017). Analisis Kelayakan Usaha Kripik Pada UD Mawar di Gampong Batee Ie Liek Kecamatan Samalanga Kabupaten Bireuen. Jurnal S. Pertanian, 1(2), 116124.

https://media.neliti.com/media/publicati ons/210819-analisis-kelayakan-usahakeripik-pada-ud.pdf

Santosa, R., (2017). Kelayakan finansial dan nilai tambah usaha agroindustri keripik ubi kayu di kecamatan saronggi kabupaten sumenep Cemara*).

Sipayung, M. L., \& Ginting, R. A. (2020). Analisis Nilai Tambah Pengolahan Ubikayu. Jurnal Agrilink Vo.2(2) 62-70

Utami, P., \& Dumasari. (2014). Strategi Pengembangan Usaha Bisnis Pangan Lokal Olahan Ubikayu di Kabupaten Banyumas. Agritech, XVI, 129-138. https://doi.org/10.30595/agritech.v16i2. 1026

Wulandari, Y. W., Nuraini, V., \& Rahadini, M. D. (2019). Analisis Kelayakan Usaha Teh Mawar Pada UKM di Desa Clutang Boyolali. JPFeb Unsoed, 9, 77-84.

http://www.jp.feb.unsoed.ac.id/index.ph p/sca-1/article/view/1397 